\title{
Quality improvement in clinical documentation: does clinical governance work?
}

This article was published in the following Dove Press journal:

Journal of Multidisciplinary Healthcare

29 November 2013

Number of times this article has been viewed

\section{Mahlegha Dehghan' \\ Dorsa Dehghan ${ }^{2}$ \\ Akbar Sheikhrabori ${ }^{3}$ \\ Masoume Sadeghi ${ }^{4}$ \\ Mehrdad Jalalian ${ }^{5}$}

'Department of Medical Surgical Nursing, School of Nursing and Midwifery, Kerman University of Medical Sciences, Kerman, ${ }^{2}$ Department of Pediatric Nursing, School of Nursing and Midwifery, Islamic Azad University Kerman Branch, Kerman, ${ }^{3}$ Department of Medical Surgical Nursing, School of Nursing and Midwifery, Kerman University of Medical Sciences, Kerman, ${ }^{4}$ Research Center for Modeling in Health, Institute of Futures Studies in Health, Kerman University of Medical Sciences, Kerman, ${ }^{5}$ Electronic Physician Journal, Mashhad, Iran
Correspondence: Mahlegha Dehghan Department of Medical Surgical Nursing, Kerman University of Medical Sciences, Haft-Bagh Alavi road, Kerman, 7616913555, Iran

$\mathrm{Tel}+983205177$

Fax +98 76I 69। 3555

Email m_dehghan86@yahoo.com
Introduction: The quality of nursing documentation is still a challenge in the nursing profession and, thus, in the health care industry. One major quality improvement program is clinical governance, whose mission is to continuously improve the quality of patient care and overcome service quality problems. The aim of this study was to identify whether clinical governance improves the quality of nursing documentation.

Methods: A quasi-experimental method was used to show nursing documentation quality improvement after a 2-year clinical governance implementation. Two hundred twenty random nursing documents were assessed structurally and by content using a valid and reliable researcher made checklist.

Results: There were no differences between a nurse's demographic data before and after 2 years $(P>0.05)$ and the nursing documentation score did not improve after a 2-year clinical governance program.

Conclusion: Although some efforts were made to improve nursing documentation through clinical governance, these were not sufficient and more attempts are needed.

Keywords: nursing documentation, clinical governance, quality improvement, nursing record

\section{Introduction}

One basic and fundamental source of information in health care is the patient record, of which nursing documentation is a part. ${ }^{1}$ On the other hand, the patient record is a source of information for the patient, researchers, and legal use. It is a source of knowledge for novice nurses and potentially for nursing theory development. ${ }^{1-3}$ Although nursing documentation provides written evidence of patient progress, it should include rationales and the underlying critical thinking behind clinical decisions, interventions, and evaluations of caregivers and must comply with established standards. ${ }^{2,4}$

Nursing documentation is defined as the record of nursing care that is planned and given to individual patients and clients by qualified nurses or other caregivers under the control of a qualified nurse. In addition, nursing documentation can be used for other purposes such as quality assurance. ${ }^{5}$ Despite continuous and consistent advice from quality-improvement programs and professional bodies over several years, achieving and maintaining good standards of clinical documentation is still a problem in the health profession. ${ }^{6}$ 
"To maintain high standards, clinical governance is the main vehicle for continuously improving the quality of patient care. Clinical governance is a system through which NHS organizations are accountable for continuously improving the quality of their services and safeguarding high standards of care by creating an environment in which excellent clinical care will flourish." 7,8

Since the World Health Organization has recommended implementation of clinical governance to its members, preliminary review and discussion of the issue were developed in meetings of the Tehran University Board of Directors. As a result, implementation of clinical governance was approved in 2006. ${ }^{9}$ Accordingly, each organization that is a part of the health care industry or that is involved in the system must ensure that quality-improvement processes are in place and that they are integrated within the quality program of the organization as a whole; good practice ideas and innovations are systematically disseminated and reported; poor clinical performance is promptly addressed; and the quality of data collected to monitor clinical care meets a high standard. ${ }^{10}$

As seen in other countries, ${ }^{5,11-14}$ Iranian literature showed that the comprehensiveness and quality of nursing records were unsatisfactory. Only 5.6-17.9 percent of nursing documentation was good and the content of that nursing documentation (eg, rest and sleep status, bowel movements) was incomplete or undocumented. ${ }^{15-17}$ It seems that there was concern about the quality of nursing documentation nationally and internationally. The literature showed that some interventions may improve nursing documentation quality-including structure, process, and content, such as: emergency department (ED) nursing documentation standards, ${ }^{18,19}$ education, ${ }^{3,20-22}$ and standardized documentation systems such as the well-being, Integrity, prevention and security (VIPS) model, ${ }^{1,23}$ and organizational change. ${ }^{24}$

It appears that organizational supervision is a key factor in improving nursing documentation, as mentioned by nurses in the Hanifi and Mohammadi study. ${ }^{15}$ According to Gordon et al, repetitive educational efforts, changes in daily bedside flow sheets, and direct and extensive leadership combined with more timely and persistent audit and feedback, clear accountability, and goal alignment were necessary for substantial improvements in pain documentation. ${ }^{24} \mathrm{All}$ of these strategies are integrated in a clinical governance program. In Iran, implementation of clinical governance was a change which renewed emphasis on quality improvement and quality assurance in health care; thus, any part of the hospital, including the nursing management and staff, were included. As the implementation of health policies in Iran is centralized and there is no spatial difference among provinces, this research sought to determine the effect of clinical governance on improving nursing documentation in Kerman, Iran.

The aim of present study was to determine the effect of changing the hospital's quality management method on the quality of the documentation related to nursing. In 2007, the hospital attempted to establish a quality management system based on the International Organization for Standardization (ISO) 9000 standard. Afterwards, the hospital was unable to attain the level of quality required for the renewal of its certification, and personal and organizational attempts to improve its quality were ineffective. As a result, the hospital developed and received approval for a quality management system based on the clinical governance model established by the Iranian Health Ministry, and this model was implemented in the hospital in 2011. This change resulted in a revival of vigorous personal and organizational attempts to ensure that progress was being made in improving quality. However, since the implementation of the new system, no studies have been conducted to investigate the outcomes associated with its use, even though it contains several vitally important concepts, including clinical audits, continuous quality improvement of all aspects of health services, and improvement of all issues related to nurses and nursing care. Therefore, the goal of this study was to investigate the effects of the implementation of the new clinical governance system on the documentation of nursing quality compared to documentation in the system based on the ISO 9000 standard.

\section{Materials and methods Study design}

This was a quasi-experimental study conducted in an instructional hospital in Kerman (the largest city in southeastern Iran with a population of 534,441) where clinical governance was being actively implemented.

\section{Experiment}

The aims of this educational intervention were to familiarize all health care providers with the concept of clinical governance, to aid them in understanding its relevance to their jobs, and to make changes in organizational culture, behavior, and attitude in order to increase personnel responsibility and accountability for quality and quality improvement. We were particularly interested in arrangements for promoting the quality of the documentation associated with nursing duties and performance. From January 2011 to December 2012, 57 2-hour sessions were conducted for head nurses and nursing supervisors concerning the concepts of clinical governance (Table 1). Head nurses and 
Table I Content and goals in the clinical governance training course

\begin{tabular}{|c|c|c|c|}
\hline Topic & Content & Specific goal & Practical goal \\
\hline $\begin{array}{l}\text { Introduction to } \\
\text { clinical governance }\end{array}$ & $\begin{array}{l}\text { History of quality improvement systems, } \\
\text { clinical governance definition, clinical } \\
\text { governance key elements, clinical governance } \\
\text { goals, and clinical governance advantages }\end{array}$ & $\begin{array}{l}\text { Enabling health care providers } \\
\text { to describe clinical governance, } \\
\text { and its objectives }\end{array}$ & $\begin{array}{l}\text { Health care providers' benefits } \\
\text { by implementing clinical } \\
\text { governance in practice }\end{array}$ \\
\hline $\begin{array}{l}\text { Key topics in } \\
\text { clinical governance }\end{array}$ & $\begin{array}{l}\text { Clinical governance models, and clinical } \\
\text { governance: seven column model }\end{array}$ & $\begin{array}{l}\text { Enabling health care providers } \\
\text { to explain clinical governance: } \\
\text { seven column model }\end{array}$ & $\begin{array}{l}\text { Enabling health care providers } \\
\text { to apply components of clinical } \\
\text { governance }\end{array}$ \\
\hline $\begin{array}{l}\text { Patients' and } \\
\text { the public's } \\
\text { involvement }\end{array}$ & $\begin{array}{l}\text { Definition and goal of patients' and the } \\
\text { public's involvement, advantages of patients' } \\
\text { and the public's involvement, determining } \\
\text { whom to involve and how, and innovations } \\
\text { in health system of other countries for the } \\
\text { involvement of patients and the public }\end{array}$ & $\begin{array}{l}\text { Enabling health care providers } \\
\text { to understand the necessity of } \\
\text { participating in patients' and the } \\
\text { public's health care planning }\end{array}$ & $\begin{array}{l}\text { Enabling health care providers } \\
\text { to involve patients and the } \\
\text { public in their health care } \\
\text { planning }\end{array}$ \\
\hline $\begin{array}{l}\text { Education and } \\
\text { training }\end{array}$ & $\begin{array}{l}\text { Personal development plan and its } \\
\text { components and goals, documentation of } \\
\text { personal development plan, providing some } \\
\text { practical examples }\end{array}$ & $\begin{array}{l}\text { Enabling health care providers to } \\
\text { learn how to prepare a personal } \\
\text { development plan }\end{array}$ & $\begin{array}{l}\text { Enabling health care providers } \\
\text { to develop their own personal } \\
\text { development plans }\end{array}$ \\
\hline $\begin{array}{l}\text { Risk management } \\
\text { and patients' safety }\end{array}$ & $\begin{array}{l}\text { Introduction to risk management and patients' } \\
\text { safety, medical errors and their etiology, } \\
\text { planning errors, execution errors, intentional } \\
\text { and unintentional errors, risk management } \\
\text { and its stages, including creating appropriate } \\
\text { contexts, identifying risks, risk analysis, dealing } \\
\text { with risk, assessment of risk management, } \\
\text { learning from errors, error reporting system, } \\
\text { and root cause analysis }\end{array}$ & $\begin{array}{l}\text { Enabling health care providers } \\
\text { to learn and practice facing risks }\end{array}$ & $\begin{array}{l}\text { Enabling health care providers } \\
\text { to deal with risks and report } \\
\text { errors }\end{array}$ \\
\hline Use of information & $\begin{array}{l}\text { Introduction to and goals of information } \\
\text { systems, data collection, and documentation; } \\
\text { Health Information System (HIS); EHR }\end{array}$ & $\begin{array}{l}\text { Enabling health care providers } \\
\text { to learn how to gather data } \\
\text { documentation }\end{array}$ & $\begin{array}{l}\text { Enabling health care providers } \\
\text { to gather data and prepare } \\
\text { documentation correctly }\end{array}$ \\
\hline $\begin{array}{l}\text { Clinical } \\
\text { effectiveness }\end{array}$ & $\begin{array}{l}\text { Evidence-based medicine (EBM) and the need } \\
\text { for its implementation, guidelines for evidence- } \\
\text { based clinical decision making }\end{array}$ & $\begin{array}{l}\text { Enabling health care providers to } \\
\text { understand the necessity of EBM }\end{array}$ & $\begin{array}{l}\text { Enabling health care providers } \\
\text { to provide evidence-based care }\end{array}$ \\
\hline Clinical audits & $\begin{array}{l}\text { The clinical audit cycle and its stages, including } \\
\text { selecting a topic for auditing, the audit team, } \\
\text { setting objectives and standards, sampling, data } \\
\text { collection, data analysis, report of findings, } \\
\text { applying changes, re-auditing, publication of } \\
\text { results, ethics }\end{array}$ & $\begin{array}{l}\text { Enabling health care providers to } \\
\text { understand the necessity of clinical } \\
\text { audits and their implementation }\end{array}$ & $\begin{array}{l}\text { Enabling health care providers } \\
\text { to form audit teams }\end{array}$ \\
\hline $\begin{array}{l}\text { Staff and staff } \\
\text { management }\end{array}$ & $\begin{array}{l}\text { Determine the suitability of employees' } \\
\text { duties, methods to persuade employees to } \\
\text { do things better, types of rewards, teamwork } \\
\text { and its management, leadership at the } \\
\text { organizational level, leadership at the } \\
\text { professional and personal levels }\end{array}$ & $\begin{array}{l}\text { Enabling health care providers } \\
\text { to understand the importance } \\
\text { of teamwork and leadership }\end{array}$ & $\begin{array}{l}\text { Enabling health care providers } \\
\text { to participate actively in } \\
\text { teamwork }\end{array}$ \\
\hline
\end{tabular}

Abbreviations: EBM, evidence-based medicine; EHR, electronic health records.

supervisors were required to attend these sessions, and they were responsible for transferring the information to their personnel. Also, 22 such workshops were conducted for members of the nursing staff. Participation in the clinical governance workshops was not required for nursing staff, although they were encouraged to attend. Hospital management and nursing service management were responsible for conducting the workshops, and the workshops were taught by hospital personnel, university faculty members, and four general physicians. One instructor was a nursing service manager who had a Master's in business administration (MBA) degree and had worked for 20 years as a nursing service manager. The university faculty member who participated in the workshops held a doctorate in philosophy $(\mathrm{PhD})$ degree in health education, and the four physicians were from the Providence Health Center and Kerman University of Medical Sciences. In addition to the training sessions on clinical governance, two 5-hour workshops were conducted by nursing faculty members for nurses and nursing assistants 
to specifically address nursing documentation. Attendance at these workshops by nurses and nursing assistants was voluntary. The head nurses were instructed to review nursing documentation more closely. In addition, two forms were added to patient records to increase the quality of documentation, one form with the patient's instructions and one form for the patient to assess nursing quality.

\section{Evaluation}

A checklist including two parts (structure and content) was used in order to determine the effect of changes in the hospital quality improvement system from the ISO standard to clinical governance. The checklist also included an assessment of the effects of conducting specialized and non-specialized training sessions on the quality of nursing documentation.

\section{Sampling}

Documentation of medical records by nurses in the first quarter of 2010 (January-March, 2010; pre-implementation of clinical governance) and the fourth quarter of 2012 (October-December, 2012; post-implementation of clinical governance) were assessed. Random stratified sampling was used and 220 records were chosen at random. All units of the hospital were divided into two groups: medical surgical and intensive care unit (ICU). Fifty-five samples were chosen randomly from each group before and after intervention. Because of some specific differences between documentation of admission and discharge notes, these were excluded from the study. Before sampling, the researcher intended to conduct the study with three subgroups: medical surgical, ICU, and emergency. However, after sampling, the emergency unit was excluded due to a lack of updated nursing documentation (ie, nursing documentation beyond admission and discharge notes).

\section{Measurement tool and study variables}

Socio-demographic data, such as sex, type of unit, educational degree of the documenter, and work shift (morning, afternoon, night) were extracted from the records. Other variables, such as age, marital status, experience, type of employment, and participation in training workshop were obtained from personnel records and nursing management.

A researcher made checklist (Table 2) was used to assess the documentation's structure and content. The structure section contains 16 items (item 16 had nine sub-items) arranged by a three-point Likert scale (complete record $=2$; incomplete record $=1$; no record $=0$ ). Some of the items in the scale included patient demographic data, nurse signa- ture, and use of correct abbreviations. The content section includes 19 items (items 12, 13, and 17 had three, three, and nine sub-items, respectively) ranked by a four-point Likert scale (complete record $=3$; incomplete record $=2$; not recorded $=1$; not necessary $=0$ ). Some of the items concerned sleep and rest statuses, bowel movements, urination, diet, and appetite.

Content validity was used to validate the checklist. Therefore, the researcher prepared the checklist by studying standards and texts and presented them to some experts to determine the proportionality of each item based on a fivepoint Likert scale (quite appropriate, appropriate, no idea, inappropriate, quite inappropriate). With this method, "quite appropriate" and "appropriate" options were considered as the validity coefficient of each question and their averages as the validity coefficient of the checklist. The validity coefficient of each item ranged from 0.72 to 1 and the validity coefficients of structure and content were $91.7 \%$ and $96.7 \%$, respectively. The total validity coefficient of the instrument was $95.3 \%$. To determine reliability of the checklist, inter-rater reliability was used and the Kappa coefficient was $81.74 \%$. The total score was calculated based on 100 and was placed in five categories: very bad (0-19.9), bad (20-39.9), average (40-59.9), good (60-79.9), and very good (80-100).

\section{Statistical analysis}

Descriptive statistics (frequency and percentage, mean, and standard deviation) and analytical statistics (paired $t$-test, chi square, Fisher exact test) were used to analyze the data. To study differences between variables and documentation quality, analysis of variance (ANOVA) was used. SPSS version 16 (IBM Corporation, Armonk, NY, USA) was used to analyze the data. The $0.05 \%$ significance level and $10 \%$ type- 2 error were used in this study.

\section{Results}

From a total 400 hospital nursing staff members, more than $85 \%$ participated in at least one of the training sessions on clinical governance. Of the study sample, $87 \%$ participated at least in one of the training sessions. Nineteen percent of the nurses participated in the specialized documentation workshops. The common reasons for not attending the training sessions and workshops were that the scheduled times were inappropriate and that the nurses had to work their shifts; usually, sessions and workshops were scheduled during the morning shift, ie, from 8:00 AM until noon. Also, the nurses' shifts and their family requirements prevent their staying longer in the 
Table 2 Updated nursing documentation auditing checklist

\begin{tabular}{|c|c|c|c|c|c|}
\hline No & Structure & $\begin{array}{l}\text { Complete } \\
\text { record }\end{array}$ & $\begin{array}{l}\text { Incomplete } \\
\text { record }\end{array}$ & $\begin{array}{l}\text { No } \\
\text { record }\end{array}$ & $\begin{array}{l}\text { Not } \\
\text { necessary }\end{array}$ \\
\hline $\mathrm{I}$ & Patient demographic data & & & & \\
\hline 2 & Unclear terms & & & & \\
\hline 3 & Estimates and assumptions & & & & \\
\hline 4 & Unauthorized abbreviation & & & & \\
\hline 5 & Repetitive issue & & & & \\
\hline 6 & Use braces and parentheses to add new content & & & & \\
\hline 7 & Leave space & & & & \\
\hline 8 & Use correct writing & & & & \\
\hline 9 & Appropriate medical terminology & & & & \\
\hline 10 & Legible, clean and tidy recording & & & & \\
\hline 11 & Coherence and relevance of reported & & & & \\
\hline 12 & Writing with black or blue pen & & & & \\
\hline 13 & Written by two different people & & & & \\
\hline 14 & Write the exact time of 24 hours & & & & \\
\hline 15 & Mistakes & & & & \\
\hline \multirow[t]{10}{*}{16} & To finish correctly & & & & \\
\hline & - nurse name & & & & \\
\hline & - nurse surname & & & & \\
\hline & - nurse position & & & & \\
\hline & - nurse degree & & & & \\
\hline & - exact date & & & & \\
\hline & - exact hour & & & & \\
\hline & - stamp of name along with the number of nursing & & & & \\
\hline & - signature & & & & \\
\hline & - draw a line across the useable space before and after the signing & & & & \\
\hline No & Content & & & & \\
\hline 1 & Urinary status & & & & \\
\hline 2 & Bowel movement & & & & \\
\hline 3 & Sleep and rest & & & & \\
\hline 4 & Diet and appetite & & & & \\
\hline 5 & Activity & & & & \\
\hline 6 & Vital signs in chart & & & & \\
\hline 7 & Pain & & & & \\
\hline 8 & Patient teaching & & & & \\
\hline 9 & Follow up issue & & & & \\
\hline 10 & Radiography & & & & \\
\hline 11 & Laboratory tests & & & & \\
\hline \multirow[t]{4}{*}{12} & Transferring patients to the operating room & & & & \\
\hline & - Time of departure for surgery & & & & \\
\hline & - Time back & & & & \\
\hline & - General condition of the patient after surgery & & & & \\
\hline \multirow[t]{4}{*}{13} & Transferring patients to other wards or hospitals & & & & \\
\hline & - Transfer time & & & & \\
\hline & - How transferring & & & & \\
\hline & - Staff who accompany patient & & & & \\
\hline 14 & Reason of not doing an order & & & & \\
\hline 15 & Telephone orders & & & & \\
\hline 16 & Safety devices such as bedside rails & & & & \\
\hline \multirow[t]{7}{*}{17} & Essential information about medications & & & & \\
\hline & - Drug name & & & & \\
\hline & - Type of drug & & & & \\
\hline & - Drug dosage & & & & \\
\hline & - Time of administration & & & & \\
\hline & - Route of administration & & & & \\
\hline & - Intravenous fluids' number of drops & & & & \\
\hline
\end{tabular}


Table 2 (Continued)

\begin{tabular}{|c|c|c|c|c|c|}
\hline No & Structure & $\begin{array}{l}\text { Complete } \\
\text { record }\end{array}$ & $\begin{array}{l}\text { Incomplete } \\
\text { record }\end{array}$ & $\begin{array}{l}\text { No } \\
\text { record }\end{array}$ & $\begin{array}{l}\text { Not } \\
\text { necessary }\end{array}$ \\
\hline & $\begin{array}{l}\text { - Intravenous fluids administration: Start time } \\
\text { - Intravenous fluids administration: Time off } \\
\text { - Patient's response to medication }\end{array}$ & & & & \\
\hline 18 & $\begin{array}{l}\text { Detailed record of the events that happened to the patient like } \\
\text { cardiopulmonary resuscitation }\end{array}$ & & & & \\
\hline 19 & Nursing care or observation & & & & \\
\hline
\end{tabular}

hospital. Another factor was that some of the nurses had already accumulated the required 15 training scores for the year, and they saw no need to participate in additional training.

In total, 220 medical records (110 before implementation of clinical governance and 110 after) were assessed. Three nursing records in ICU before implementation $(n=55)$ and two nursing records in ICU after implementation $(n=55)$ and four nursing records in medical-surgical units after implementation $(n=55)$ had no name or signature. One set of documentation from the medical-surgical units was not recorded after implementation of clinical governance ( $\mathrm{F}=0.18, P>0.05)$. Before intervention, $93.3 \%$ of nurses and after intervention, $92 \%$ of nurses who wrote nursing documentation were females $(P>0.05)$. The mean ages of nurses before and after implementation of clinical governance were $31.4 \pm 6.63$ years and $31.36 \pm 6.16$ years, respectively. Seventy-eight percent of nurses before intervention and $65.7 \%$ of nurses after implementation were married $(P>0.05)$.

Length of nursing experience before and after intervention was 77.54 \pm 94.26 months and $64.51 \pm 76.25$ months, respectively $(P>0.05)$. Nurses with a bachelor's of science (BSc) in nursing wrote $69.8 \%$ of the nursing documentation before intervention and wrote $84.6 \%$ of the post-implementation documentation studied. Statistically, there were no significant differences between these two groups $(P>0.05)$. Regarding employment status, before intervention, $25.8 \%$ were hired, $36.6 \%$ were contract workers (type 1 ), $34.4 \%$ were contract workers (type 2 ) and 3.2\% were committed. The variables here were $14 \%, 32 \%, 38 \%$, and $16 \%$, respectively, after intervention. There was no significant difference between these two groups $(P>0.05)$. Before intervention, $17.4 \%$ of nurses and after intervention $19 \%$ of nurses had participated in a documentation training workshop $(P>0.05)$. Before intervention, $33.6 \%$ of documentation was written during a morning shift, 30\% in an afternoon shift, and 36.4\% during a night shift. After intervention, the ratio was 39.6\%, 30.2\%, and $30.2 \%$, respectively. Regarding the sampling method, the number of nursing records controlled in medical-surgical units was similar to that of ICUs (Table 3 ).

Before implementation of clinical guidance, the mean quality score of nursing documentation was $2.22 \pm 0.2$. After implementation of clinical governance, it was $2.24 \pm 018$. Statistically there was no significant difference between these groups ( $P>0.05$; Table 4$)$. The calculation of the quality score was based on 100 . Before implementation of clinical governance, $1.8 \%$ of nursing documentation was bad, $45.5 \%$ was average, $51.8 \%$ was good, and $0.9 \%$ was very good. Of that documentation, $91.8 \%$ was good or very good structurally. Only $23.6 \%$ was good from a content perspective. After intervention, we saw no nursing documentation that ranked in the "bad" quality category, $40 \%$ was average, $56.9 \%$ was good, and $2.8 \%$ was very good. Also, $92.7 \%$ and $22.2 \%$ of nursing documentation structure and content scores were good and very good, respectively.

The results were obtained from an ANOVA that showed a significant difference between quality scores and units and between quality scores and type of employment ( $\mathrm{F}=41.05$, $P<0.001, \mathrm{~F}=5.45, P=0.001$, respectively). Also, Eta square value was 0.16 and 0.08 , respectively. This means that the type of unit where the nurses worked and the type of employment can predict $16 \%$ and $8 \%$ of nursing documentation quality scores, respectively. On the other hand, the quality of nursing documentation in the intensive care units is $16 \%$ higher than that found in medical-surgical units. Eight percent of nursing documentation written by committed nurses was higher in quality than other employed groups. Note that there was no significant difference between other variables and quality scores (Table 5).

\section{Discussion}

We found that no significant difference in nursing documentation quality scores (either structure or content) before and after a 2-year implementation of clinical governance. Also, there were significant differences between medical-surgical 
Table 3 Variables distribution before and after clinical governance

\begin{tabular}{|c|c|c|c|}
\hline Variables & $\begin{array}{l}\text { Before clinical } \\
\text { Governance }(n=|| 0)\end{array}$ & $\begin{array}{l}\text { After clinical } \\
\text { Governance }(n=|| 0)\end{array}$ & Test statistic \\
\hline \multicolumn{4}{|l|}{ Nursing records } \\
\hline Having nurse's name & 107 (97.27\%) & $103(93.60 \%)$ & $\begin{array}{l}\text { Fisher's exact } \\
\text { test }=0.18\end{array}$ \\
\hline Not having nurse's name & $3(2.73 \%)$ & $6(5.45 \%)$ & $P=0.84$ \\
\hline Undocumented & 0 & $\mathrm{I}(0.95 \%)$ & \\
\hline \multicolumn{4}{|l|}{ Unit } \\
\hline Medical-surgicals & 55 (50.00\%) & $55(50.00 \%)$ & $\mathrm{F}=0$ \\
\hline ICUs & $55(50.00 \%)$ & $55(50.00 \%)$ & $P>0.99$ \\
\hline \multirow[t]{2}{*}{ Age (year) } & Mean $=31.40$ & Mean $=31.36$ & $\mathrm{t}=0.80$ \\
\hline & $S D=6.63$ & $S D=6.16$ & $P=0.90$ \\
\hline \multirow[t]{2}{*}{ Nursing experience (month) } & Mean $=77.54$ & Mean $=64.5 \mathrm{I}$ & $\mathrm{t}=0.99$ \\
\hline & $\mathrm{SD}=94.26$ & $S D=76.25$ & $P=0.32$ \\
\hline \multicolumn{4}{|l|}{ Sex ${ }^{1,2}$} \\
\hline Female & $98(93.30 \% *)$ & $93(92.10 \%)$ & $\begin{array}{l}\text { Fisher's exact } \\
\text { test }=0.60\end{array}$ \\
\hline Male & 7 (6.70\%) & $8(7.90 \%)$ & $P=0.58$ \\
\hline \multicolumn{4}{|l|}{ Marital status ${ }^{1,2}$} \\
\hline Single & 19 (20.90\%) & $32(32.30 \%)$ & $\chi^{2}=6.01$ \\
\hline Married & 7I (78.00\%) & $65(65.70)$ & $P=0.20$ \\
\hline Others & $\mathrm{I}(\mathrm{I} .10 \%)$ & $2(2.00 \%)$ & \\
\hline \multicolumn{4}{|l|}{ Degree $^{1,2}$} \\
\hline Diploma in nursing & $32(30.20 \%)$ & $16(15.40 \%)$ & $\begin{array}{l}\text { Fisher's exact } \\
\text { test }=0.05\end{array}$ \\
\hline Bachelor of nursing & 74 (69.80\%) & $88(84.60 \%)$ & $P=0.50$ \\
\hline M.Sc. in nursing & 0 & 0 & \\
\hline \multicolumn{4}{|l|}{ Type of employment ${ }^{1,2}$} \\
\hline Hired & $24(25.80 \%)$ & $14(14.00 \%)$ & $\chi^{2}=8.40$ \\
\hline Contract recruiters- $\mathrm{I}^{\mathrm{a}}$ & $34(36.60 \%)$ & $32(32.00 \%)$ & $P=0.50$ \\
\hline Contract recruiters- $2^{\mathrm{b}}$ & $32(34.40 \%)$ & $38(38.00 \%)$ & \\
\hline Committed & $3(3.20)$ & $16(16.00 \%)$ & \\
\hline \multicolumn{4}{|l|}{ Shift $^{3}$} \\
\hline Morning (7:30-13:30) & 37 (33.60\%) & $42(39.60 \%)$ & $\chi^{2}=4.50$ \\
\hline Afternoon (13:30-19:30) & $33(30.00 \%)$ & $32(30.20 \%)$ & $P=0.34$ \\
\hline Night (19:30-7:30) & $40(36.40 \%)$ & $32(30.20 \%)$ & \\
\hline \multicolumn{4}{|c|}{ Attendance in training workshop $p^{1,2}$} \\
\hline Yes & $16(17.40 \%)$ & $19(19.00 \%)$ & $\begin{array}{l}\text { Fisher's exact } \\
\text { test }=0.09\end{array}$ \\
\hline No & $76(82.60 \%)$ & 81 (81.00\%) & $P=0.56$ \\
\hline
\end{tabular}

Notes: Missing data in variables were because of: I) some documentation had no nurse signature to identify the nurse's demographic data; 2 ) some nurses were no longer at the hospital and no data about them existed; 3) researcher-made missing. *Valid percentage; annually contracted with payment similar to hired nurses; bannually contracted with payment less than hired nurses; 'it is obligatory to work for government for two years at a lower rate of pay.

Abbreviations: ICU, intensive care unit; M.Sc., Master of Science; SD, standard deviation.

units and the ICU in quality scores and among type of employment as well.

Despite an extensive search, we could not access relevant articles and we could not find any article to support our findings. In a study by Björvell et al, after a 2-year intervention of organizational changes and education in accordance with the VIPS model designed to structure nursing documentation, there was a significant score increase in quantity and quality of nursing documentation. However, the record audit revealed a less than adequate quality of nursing documentation. ${ }^{21}$ Another study showed that application of the VIPS model significantly improved nursing documentation and nurses' familiarity with nursing diagnoses, goals, and interventions. ${ }^{23}$ The difference between our study and the afore mentioned findings may be due to a lack of a structured, integrated style of nursing documentation and because most Iranian nurses do not use a model based on a nursing process and there is no professional requirement to do so. It is not obvious for nurses how to provide care and write it down systematically. Unlike our findings, in some studies, nursing 
Table 4 Quality of nursing documentation before and after clinical governance

\begin{tabular}{llll}
\hline & $\begin{array}{l}\text { Before clinical } \\
\text { governance } \\
\text { (mean } \pm \text { SD) }\end{array}$ & $\begin{array}{l}\text { After clinical } \\
\text { governance } \\
\text { (mean } \pm \text { SD) }\end{array}$ & $\begin{array}{l}\text { Test } \\
\text { statistic }\end{array}$ \\
\hline $\begin{array}{l}\text { Nursing documentation } \\
\text { quality score }\end{array}$ & $2.22 \pm 0.20$ & $2.24 \pm 0.18$ & $\begin{array}{l}\mathrm{t}=-0.80 \\
\text { Structure }\end{array}$ \\
& $2.48 \pm 0.20$ & $2.48 \pm 0.12$ & $\begin{array}{l}P=0.42 \\
\mathrm{t}=0.00\end{array}$ \\
& $1.89 \pm 0.36$ & $1.97 \pm 0.34$ & $\begin{array}{l}P>0.99 \\
\mathrm{t}=-0.99 \\
P=0.33\end{array}$ \\
\hline
\end{tabular}

Abbreviation: SD, standard deviation.

documentation improved after continuing education was provided regarding both structure and content. ${ }^{20,22}$ In one study, to evaluate nursing documentation performance, the researchers created a scenario and asked nurses to document it. ${ }^{20}$ This method did not appear to assess nursing documentation quality appropriately because the situation was fictitious. Also, in this study, just 3 days after intervention, the quality of nursing documentation was assessed-this may be too little time to achieve a well-established documentation process. In the other study, checklist reliability was not noted, and the items of checklist did not seem to be comprehensive. ${ }^{22}$

As our results show, more than $90 \%$ of structure scores and less than $25 \%$ of content scores were good and very good. So, our nursing documentation is poor in content, which must be addressed. Results by Khoddam et al sup-

Table 5 Differences between nursing documentation quality score and variables

\begin{tabular}{|c|c|c|}
\hline & ANOVA & Eta squared \\
\hline \multirow[t]{2}{*}{ Quality score * groups } & $\mathrm{F}=0.58$ & 0.00 \\
\hline & $P=0.45$ & \\
\hline \multirow[t]{2}{*}{ Quality score * unit } & $\mathrm{F}=4 \mathrm{I} .05$ & 0.16 \\
\hline & $P<0.001$ & \\
\hline \multirow[t]{2}{*}{ Quality score * shift } & $\mathrm{F}=2.34$ & 0.02 \\
\hline & $P=0.10$ & \\
\hline \multirow[t]{2}{*}{ Quality score * marital status } & $\mathrm{F}=0.08$ & 0.00 \\
\hline & $P=0.90$ & \\
\hline \multirow[t]{2}{*}{ Quality score * degree } & $\mathrm{F}=1.57$ & 0.00 \\
\hline & $P=0.20$ & \\
\hline \multirow[t]{2}{*}{ Quality score * type of employment } & $\mathrm{F}=5.45$ & 0.08 \\
\hline & $P=0.00 \mathrm{I}$ & \\
\hline \multirow[t]{2}{*}{ Quality score* sex } & $\mathrm{F}=\mathrm{I} .17$ & 0.01 \\
\hline & $P=0.28$ & \\
\hline \multirow[t]{2}{*}{ Quality score* age } & $\mathrm{F}=\mathrm{I} .45$ & 0.19 \\
\hline & $P=0.08$ & \\
\hline \multirow[t]{2}{*}{ Quality score * nursing experience } & $\mathrm{F}=1.32$ & 0.45 \\
\hline & $P=0.09$ & \\
\hline Quality score * attendance in training & $\mathrm{F}=0.05$ & 0.00 \\
\hline workshop & $P=0.80$ & \\
\hline
\end{tabular}

Note: *Association between two variables. Abbreviations: ANOVA, analysis of variance. port this finding. ${ }^{22}$ In their study, structure related nursing documentation scores were higher than content scores. Gunningberg et al showed that the comprehensiveness and quality of nursing records were unsatisfactory and only three of 55 records reached the level required by Swedish law. ${ }^{25}$ In another study, considerable numbers of deficiencies (such as adding a professional signature, correctly writing abbreviations, and assessing patient basic needs) were identified in the daily recordkeeping of nursing care. ${ }^{26}$ In another study, only $5.6 \%$ of nursing documentation was good, the content of nursing documentation (eg, rest and sleep status, bowel movements) was incomplete or undocumented, and patient demographic data, nurse signature, and date were absent. ${ }^{17}$

Uys and Booyens reported that the number of registered nurses and non-nursing support staff as well as the type of unit, made a significant difference in the quality of documentation. ${ }^{27}$ In our study, the absence of a significant difference between nurses' education and the quality of their documentation may be a result of not having well-defined role characteristics in Iran, and nearly all care providers do the same role. Rather, we found the difference between type of employment and nursing documentation score significant: committed nurses fared better. These nurses may be more motivated by future job opportunities and most have recently graduated and are fresh and not accustomed to work. We inferred from our results that the difference between type of unit and quality of nursing documentation is due to the content score. ICUs and medical-surgical units provide inherently different care, both in quantity and quality. So, this finding was predictable.

Ghazanfari et al found a significant difference between documentation training workshop participation, and quality of documentation, but not with other variables such as type of employment, type of ward, and age, etc. ${ }^{16}$ Our findings suggest that the quality of documentation does not significantly differ with participation in the workshop. This should be considered to improve nursing documentation and patient care planning. It is not enough to increase knowledge in the use of documentation. Organizational and leadership issues must be addressed simultaneously.

Naturally, the assessment of patient records involves subjective judgments, which is a limitation of this study. We cannot accurately determine whether documentation gaps or lapses were due to nursing carelessness or a lack of necessity for that information. Another limitation was a large effect size. Although there were some improvements in nursing documentation after the clinical governance 
implementation, the difference was not significant. Note that, although the implementation of clinical governance was required and its principles were clear, it is not known how well it was applied.

Considering that the clinical governance model is a new concept in Iran, one of the common limitations for implementing the model is that nurses, who already have a high workload and a very demanding schedule, have very little motivation to participate in additional training sessions.

\section{Conclusion}

Although some efforts were made to improve nursing documentation by implementing a clinical governance program, these were not sufficient and more attempts are needed. Clinical governance should not only offer a model on which nursing documentation should be built; it should also be a requirement in Iran. Evaluation of how to provide and document nursing care simultaneously needs further studies. We recommend assessing how clinical governance can improve nursing quality and patient satisfaction. Further research and more consistent application of established standards will lead to improvements, with associated benefits for practice management and patient and organizational outcomes.

\section{Acknowledgments}

The authors thank the nurses and personnel of the medical record archives of Bahonar Hospital for their contribution to our data collection.

\section{Disclosure}

The authors report no conflicts of interest in this work.

\section{References}

1. Björvell C, Thorell-Ekstrand I, Wredling R. Development of an audit instrument for nursing care plans in the patient record. Qual Health Care. 2000;9(1):6-13.

2. Larson J, Björvell C, Billing E, Wredling R. Testing of an audit instrument for the nursing discharge note in the patient record. Scand J Caring Sci. 2004;18(3):318-324.

3. Ehrenberg A, Ehnfors M. The accuracy of patient records in Swedish nursing homes: congruence of record content and nurses' and patients' descriptions. Scand J Caring Sci. 2001;15(4):303-310.

4. Blair W, Smith B. Nursing documentation: frameworks and barriers. Contemp Nurse. 2012;41(2):160-168.

5. Wang N, Hailey D, Yu P. Quality of nursing documentation and approaches to its evaluation: a mixed-method systematic review. $J A d v$ Nurs. 2011;67(9):1858-1875.

6. Cowan J. Clinical governance and clinical documentation: still a long way to go? Clin Perform Qual Health Care. 2000;8(3):179-182.

7. Scally G, Donaldson LJ. The NHS's 50 anniversary. Clinical governance and the drive for quality improvement in the new NHS in England. BMJ. 1998;317(7150):61-65.
8. Buetow SA, Roland M. Clinical governance: bridging the gap between managerial and clinical approaches to quality of care. Qual Health Care. 1999;8(3):184-190.

9. Rashidian A. Clinical governance in Tehran medical university: Quality improvement of healthcare services, a case study. Journal of Hospital. 2009;31(5):27-32. Persian.

10. Sciacovelli L, Secchiero S, Zardo L, Zaninotto M, Plebani M. External Quality Assessment: an effective tool for Clinical Governance in laboratory medicine. Clin Chem Lab Med. 2006;44(6):740-749.

11. Davis AL, Holman EJ, Sousa KH. Documentation of care outcomes in an academic nursing clinic: an assessment. J Am Acad Nurse Pract. 2000;12(12):497-502.

12. Ehnfors M, Smedby B. Nursing care as documented in patient records. Scand J Caring Sci. 1993;7(4):209-220.

13. Ehrenberg A, Birgersson C. Nursing documentation of leg ulcers: adherence to clinical guidelines in a Swedish primary health care district. Scand J Caring Sci. 2003;17(3):278-284.

14. Eid T, Bucknall T. Documenting and implementing evidence-based post-operative pain management in older patients with hip fractures. J Orthop Nurs. 2008;12(2):90-8.

15. Hanifi N, Mohammadi E. Causes of failure to properly report writing in nursing. Hayat Journal. 2004;10(2):39-46. Persian. Available from: http://journals.tums.ac.ir/upload_files/pdf/_587.pdf. Accessed October $31,2013$.

16. Ghazanfari Z, Sheykhpour-khani M, Haghdoost AA. Nurse's knowledge and practice of the principles of nursing documentation at hospitals of kerman university of medical sciences. Iran Journal of Nursing. 2009;22(59):15-22. Persian. Available from: http://www.sid.ir/fa/ VEWSSID/J_pdf/72913885902.pdf. Accessed on October 31, 2013.

17. Hosseini Kakhk S, Amiri Parsa T, Azarnive M, Hamedinia M. The Effect of Resistance Training, Aerobic Training and Detraining on the Lipid Profile and CRP in Obese Girls. Quarterly Journal of Sabzevar University of Medical Sciences. 3 2011;18(3):188-197.

18. Considine J, Potter R, Jenkins J. Can written nursing practice standards improve documentation of initial assessment of ED patients? Aust Emerg Nurs J. 2006;9(1):11-8.

19. Törnvall E, Wahren LK, Wilhelmsson S. Advancing nursing documentation - an intervention study using patients with leg ulcer as an example. Int J Med Inform. 2009;78(9):605-617.

20. Abbaszadeh A, Sabeghi H, Heidary A, Borhani F. Assessment of the effect of continuing education program on nurse's knowledge, attitude and, performance about documentation. Journal of Evidence-Based Care. 2012;2(2):75-83. Persian.

21. Björvell C, Wredling R, Thorell-Ekstrand I. Long-term increase in quality of nursing documentation: effects of a comprehensive intervention. Scand J Caring Sci. 2002;16(1):34-42.

22. Khoddam H, Sanagoo A, Joybari L. Effect of continuing education on nursing documentation quality. Journal of Gorgan University of Medical Sciences. 2002;3(8):65-9. Persian. Available from: http://www.goums. ac.ir/journal/browse.php?a_id=136\&sid=1\&slc_lang=fa. Accessed October 31, 2013.

23. Darmer MR, Ankersen L, Nielsen BG, Landberger G, Lippert E, Egerod I. Nursing documentation audit - the effect of a VIPS implementation programme in Denmark. J Clin Nurs. 2006;15(5):525-534.

24. Gordon DB, Rees SM, McCausland MR, et al. Improving reassessment and documentation of pain management. Jt Comm J Qual Patient Saf. 2008;34(9):509-517.

25. Gunningberg L, Lindholm C, Carlsson M, Sjödén PO. The development of pressure ulcers in patients with hip fractures: inadequate nursing documentation is still a problem. JAdv Nurs. 2000;31(5):1155-1164.

26. Booyens SW, Uys LR. The quality of nursing documentation in some private and provincial hospitals in the Cape Peninsula and the PWV area. Curationis. 1989;12(1-2):26-28.

27. Uys LR, Booyens SW. Standards for nursing documentation in general hospitals in South Africa. Curationis. 1989;12(1-2):29-31. 
Journal of Multidisciplinary Healthcare

Dovepress

\section{Publish your work in this journal}

The Journal of Multidisciplinary Healthcare is an international, peerreviewed open-access journal that aims to represent and publish research in healthcare areas delivered by practitioners of different disciplines. This includes studies and reviews conducted by multidisciplinary teams as well as research which evaluates the results or conduct of such teams or healthwelcomes submission from practitioners at all levels, from all over the world. The manuscript management system is completely online and includes a very quick and fair peer-review system. Visit http://www.dovepress. com/testimonials.php to read real quotes from published authors.

Submit your manuscript here: http://www.dovepress.com/journal-of-multidisciplinary-healthcare-journal 